\title{
Has Canada Shown its Arcticness?
}

\author{
By Erica M. Dingman*
}

"It looked like the Canadians had just arrived there-they didn't seem to know the place any better than we did."

\section{Introduction}

Canada is commonly seen as an Arctic nation. While this is certainly accurate from a geographical perspective, there remains a question as to whether the nation genuinely is committed to its "Arcticness," or whether it simply evokes the image for political purposes. Another serious concern is Canada's dependence on the United States in meeting her economic and security needs, which is seen as drawing Canada's focus away from her Far North. Consequently, the Inuit (indigenous people in Canada's northern provinces) and the region as a whole lack the requisite tools and financial support indicative of a nation with significant Arctic aspirations.

With Canada's attention focused primarily on its economic and security relations, particularly with the U.S., Canada's drive to fully become an Arctic nation appears greatly diminished. Is Canada willing to balance the demands of the Canada/U.S. economic and security relationship with a commitment to developments that would be beneficial to the Inuit and the region as a whole? What are the risks and benefits associated with changing the nation's strategic vision of the Far North?

This article will attempt to address these questions. It will first examine InuitCanada relations in historical context in order to better understand a dynamic that is still struggling to overcome its colonial past. Now focused on a return to self-reliance, Inuit strategy supports community development as well as Canada's assertion of Arcticness. Second, I will examine the bond between Canada and the United States in both the security and economic realms.

* Erica Dingman is a research associate at the World Policy Institute in New York City. Her research focuses on the Arctic, Inuit, and Canada/United States relations. She holds a Masters in International Affairs from The New School. Erica was born and raised in Canada and is a longtime resident of the United States, a duality that greatly influences her research.

[Author: please insert a brief biographical statement.]

1 Comment by a European official at the G7 Iqaluit Summit, quoted in Doug Saunders, "We See our Arctic as a Colony," Globe and Mail [Toronto] (12 February 2010). 
These histories are by no means exhaustive, but are rather intended to provide background for the argument that follows. Contemporary issues that have their roots in these historical arrangements are now influencing the Arctic debate. From both the Inuit perspective and the U.S. perspective (as exemplified by the 2009 U.S. Arctic Region Policy), renewed geopolitical interest in the Arctic has been amplified, in part, by the effects of climate change, which carry a variety of security concerns. Finally, I conclude that Canada may be overlooking certain security issues presented in the U.S. Region Arctic Policy that are indeed compatible with the Inuit strategy. I hope that this article will provoke debate on aspects of Canada's relationship with its Far North and with the United States, both of which are driving Canada's claim to Arcticness.

\section{Inuit: Canada's Northern Indigenous Citizens}

Consensus opinion in Canada holds that the Arctic "is an essential part of [Canadian] national identity." 2 For decades, politicians have evoked nascent images of the "Arctic" to garner voter support through the lens of nationalism; Canadian literature depicts the Canadian North through both realist and mystical lenses; and Inuit sculpture graces the living rooms of Canadians and foreigners alike. Despite this, Mary Simon, President of Inuit Tapiriit Kanatami, argues that for the period of time from colonial rule to present, "the Arctic has been on the margins of Canadian consciousness." 3

That said, the Inuit ${ }^{4}$ of Canada have inhabited the Arctic for millennia. ${ }^{5}$ The region is vast by any standards, covering 40 percent of the Canadian landmass. ${ }^{6}$ But it is also by far the most sparsely populated region of the nation, with the majority of the Canada's 50,485 Inuit residing in the nation's northern regions of Inuvialuit Settlement Region (Northwest Territories), Nunatsiavut (Northern Labrador), Nunavik

2 Government of Canada, "The Canadian Arctic: Canadian High Commission in London Focuses on Canada's Arctic" (2010); available at http://www.canadainternational. gc.ca/united_kingdom-royaume_uni/bilateral_relations_bilaterales/arctic-arctique. aspx?lang=eng.

3 Mary Simon, "Sovereignty for the North," The Walrus (November 2007); available at Walrusmagazine.com.

4 Inuit are one of three indigenous peoples in Canada. The other two are First Nations and Métis.

5 Inuit Tapiirit Kanatami, "ITK Origins," available at http://www.itk.ca/itk-origins.

6 Government of Canada, "The Canadian Arctic." The term "Arctic" is defined in a number of different ways by the federal government, which is another cause of confusion. 
(Northern Quebec), and the Territory of Nunavut. ${ }^{7}$ The Inuit people's native lands span four countries: Canada, Denmark (Greenland), Russia (Siberia), and the United States (Alaska), with a total population of 155,000 people. Despite this broad geographic range, the Inuit are joined by a common culture and language. ${ }^{8}$

Given diminished opportunities to express their full rights, Inuit leaders and nonaboriginal scholars argue that the Inuit should be treated with due respect as Canadian citizens and as inhabitants of Canada's Far North. To meet the material and political needs of this distinct group of Canadians, Inuit Tapiriit of Canada ("Inuit will be united in Canada") was founded in 1971, as the national organization of the Inuit. The name was later changed to Inuit Tapiriit Kanatami which means "Inuit are united in Canada." From the start, a primary focus of ITK's mission was settlement of Inuit land claims. ${ }^{9}$

In 1993, after lengthy deliberations, representatives of the Inuit people and the Canadian government signed the Nunavut Land Claims Agreement. It is by far the largest land claims agreement in the history of Canada. ${ }^{10}$ The agreement led to the creation of Nunavut in 1999 as the first Inuit self-governing territory of Canada. But tensions have arisen because of issues regarding the implementation of promises made in this land claims agreement and others.

7 "2006 Census: Aboriginal Peoples in Canada in 2006: Inuit, Métis and First Nations, 2006 Census: Inuit," in Statistics Canada (Ottawa: Statistics Canada,); available at http://www12.statcan.ca/census-recensement/2006/as-sa/97-558/p6-eng.cfm. [Author: this link is non-functional—please clarify this citation]

8 Sheila Watt-Cloutier, "Bringing Inuit and Arctic Perspectives to the Global Stage: Lessons and Opportunities," Proceedings of the 14th Inuit Studies Conference: Inuit and Arctic Perspectives (Calgary: University of Calgary, 2005).

9 Inuit Tapiriit Kanatami, "About ITK," available at http://www.itk.ca/.

10 André Légaré, "Canada's Experiment with Aboriginal Self-Determination in Nunavut: From Vision to Illusion," International Journal on Minority and Group Rights 15:2 (2008): 336. 


\title{
Historical Experience of the Inuit: From Self-Reliance to De- pendency
}

\author{
"When their usefulness as allies or guides ended, the northern natives \\ became politically invisible."
}

Despite advances in Inuit/government relations, interactions are still influenced by constraints associated with Canada's colonial legacy. There is no single factor that explains this phenomenon, but rather a confluence of circumstances shaped by the dominant view of the Western experience.

Historically, Inuit survival depended on intimate knowledge of the land and sea. Indeed, Inuit possessed the skills not only to survive but also to thrive in their seemingly uninhabitable environment. This knowledge endures, but the demands of Western modernity have shaped how the Inuit negotiate their material environment and their path to self-reliance. While the federal government and Canada's mostly southern-based population focus primarily on opportunities associated with resource extraction, increased maritime traffic, and exercising sovereignty over Canada's Far North, Inuit leaders and activists seek to balance the demands of regional realities while pursuing a course relevant to the federal government. By this I mean that Inuit society, once self-reliant and self-governing, has been beleaguered by external influences that created dependency. ${ }^{12}$ Today, any Inuit-based regional strategy must reflect the specific needs of the people, increasing their capacity to regain self-reliance and prosper in a rapidly changing Arctic region where climate change has amplified its geopolitical significance.

On the federal level, the implementation of government policy and agreements (such as the Nunavut Land Claims Agreement), has frequently been sluggish, requiring the Inuit elite to remain vigilant in pursuit of Ottawa to fulfill its obligations. Exemplifying this point, Michael Byers commented, "the Canadian Government made a number of commitments in the Nunavut Land Claims Agreement that have not yet been fulfilled." 13 This resulted in the 2006 filing by Nunavut Tunngaviik, Inc. ${ }^{14}$ of a

11 Tony Penikett, A Report and Recommendations for Canadian Foreign Policy in the Circumpolar Arctic, Appendix 3, "Northern Governance: Devolution, Treaties and the Arctic Council" (Ottawa: Canadian Arctic Resources Committee, 26 April 1997).

12 Canada, House of Commons Standing Committee on Foreign Affairs and International Trade, "Canada and the Circumpolar World: Meeting the Challenges of Cooperation into the Twenty-First Century," Issue 13 (Ottawa, April 1997), 136.

13 Michael Byers, Who Owns the Arctic: Understanding Sovereignty Disputes in the North. (Vancouver: Douglas \& McIntyre, 2009), 112.

14 Nunavut Tunngavik, Inc. ensures that promises made under the Nunavut Land Claims Act are carried out. 
CAD 1 billion lawsuit against the Attorney General of Canada for breach of contract. Among numerous complaints, the lawsuit alleges that the federal government has not lived up to its obligations to provide adequate funding for Inuit organizations, boards, and commissions responsible for monitoring, planning, and regulating land development. ${ }^{15}$ The claim has moved along slowly; at the time of this writing, the claim is still at the discovery stage.

In essence, land claim agreements are a means for the Inuit to have a voice in government and gain control over their lands. By not living up to its end of the bargain, Paul Kaludjak argues, "the Government of Canada keeps Inuit dependent and in a state of financial and emotional despair." 16 Gaps between Inuit strategic interests and the federal government are slowly closing, but disparities continue to plague the local community in its ability to move forward. At present, the socio-economic conditions of Canadian Inuit can best be described as tenuous. Under a century of Western domination, the Inuit social, political, and economic systems eroded to the extent that the population had become wards of the state by the $1950 \mathrm{~s} .{ }^{17}$ The following section briefly describes how this occurred.

Traditionally a nomadic people, the Inuit see themselves as "Part of the Land, Part of the Water." ${ }^{18}$ Hunting and fishing were critical to Inuit life and culture. For instance, caribou, seal, and walrus provided sustenance, while pelts were used for clothing and tents, and bones were carved into harpoons or other tools. This tradition continues to some extent, and in a vivid account of Inuit hunting practices, Arnaitok Aipeeliup notes that along with all harvested animals "The whole caribou was used for food," 19 clothing shelter and tools. It remains an important aspect of Inuit tradition. Inuit political and economic traditions reflected the specific needs of the people, and remain important guiding principles of present day Inuit society. E. F. Roots, a respected Arctic environmental scientist of the 1990s, described the indigenous economy as "small scale, attuned to local needs and responses, fluctuating with changes in natural conditions, and although with many ups and downs, providing the people within it with a culture and society that by any world standards must be considered successful." 20

15 Luis Millan, "Climate Change Intersects with Inuit Land Claims Agreements," The Lawyers Weekly (23 April 2010).

16 Ibid., 20.

17 André Légaré, "Canada's Experiment with Aboriginal Self-Determination in Nunavut: From Vision to Illusion," International Journal on Minority and Group Rights 15:2 (2008): 342.

18 Penikett, "Northern Governance." This is the title of a novel by Hugh MacLennan.

19 Arnaitok Aipeeliup, “The Old Ways Of The Inuit: Inuit Piusiviningit," Inuktitut Magazine 78 (Ottawa: Summer 1995) 21-39.

20 Quoted in Penikett, "Northern Governance." 
For the most part, the Inuit of Canada remained unaffected by Western customs until the nineteenth century. ${ }^{21}$ However, the people's initial contact with European whalers brought disease and alcohol, which had devastating effects on the Inuit population: by 1910, the Inuit population in the Mackenzie Valley Delta had fallen from 2,000 to $130 .{ }^{22}$ Before they became subject to European influence, the Inuit "were free to govern [their] lives and manage [their] territory according to Inuit needs and ways of doing things," 23 employing the tradition of consensus decision-making.

The earliest Inuit encounters with Europeans date back to Erik the Red's tenthcentury voyages to Newfoundland and Labrador. ${ }^{24}$ However, these non-indigenous peoples generally found the terrain and weather foreboding, and did not establish permanent settlements. Early explorers travelling the northernmost parts of the North American continent learned the harsh truth. While explorers such as Martin Frobisher and Samuel Hearne successfully navigated the Far North in 1578 and 1771, respectively, many others perished. In 1611, Henry Hudson was left to die in his final venture to the Hudson Strait and into Hudson Bay. Failing to learn the lessons of his forebears, John Franklin and his crew took their final, ultimately fatal voyage in 1846 as they attempted to complete the charting of the Northwest Passage. ${ }^{25}$

The twentieth century saw the onset of Inuit dependency, prompted by European desire for the pelts of northern animals such as white fox. The "company adventurers" of the Hudson's Bay Company (HBC), ${ }^{26}$ who were the main conductors of the fur trade in the region, ventured north, requiring the assistance of Inuit hunters and guides. Consequently, the tradition of hunting for survival slowly gave way to commercial trapping. Though some Inuit remained semi-nomadic, many organized communities around $\mathrm{HBC}$ trading posts to ease the process of trade.

"The introduction of the fur trade," noted André Légaré, "changed Inuit lifestyle forever, creating an economic relationship of dependency." The Inuit received European

21 Sarah Bonesteel, "Canada's Relationship with Inuit: A History of Policy and Program Development," Government of Canada, Indian and Northern Affairs Canada (June 2006), 9; available at http://www.ainc-inac.gc.ca/ai/rs/pubs/rsh4_1-eng.asp\#chp3.

22 UNHCR, Refworld, World Directory of Minorities and Indigenous Peoples, "Canada: Inuit,” available at http://www.unhcr.org/refworld/country,,MRGI,,CAN,,49749d403 c, 0. html.

23 Inuit Tapiirit Kanatami, "ITK Origins," available at http://www.itk.ca/itk-origins.

24 Bonesteel, "Canada's Relationship with Inuit," 1.

25 Kenneth Coates, Whitney Lackenbauer, William Morrison, and Greg Poelzer, Arctic Front: Defending Canada in the Far North (Toronto: Thomas Allen, 2010), 11-15.

26 At the time of incorporation, the men who ventured to the new land were formally referred to as the "Company Adventurers trading into Hudson's Bay." In the interests of accuracy, in should be noted that the French trading company, Revillon Frères, were the first recorded traders in the north. 
goods like ammunition, tea, and tobacco a year in advance of the hunt, establishing a system of credit and debt, along with a taste for imported goods. ${ }^{27}$

In addition, the practice of treaty-making shaped the historical experience of Inuit/colonizer-trader relations. Seeking a means of organizing its North American colonies and stabilizing relations with indigenous peoples, Britain issued the Royal Proclamation of 1763, which permitted Britain to purchase land from the indigenous peoples and in turn sell it to colonizers.

When Canada attained Dominion in 1867, treaty-making assumed a distinctly different tone, one that ignored the intent of the Royal Proclamation. Initially considered a closed chapter, Canada's vision of transcontinental railways renewed interest in the pursuit of treaties. However, to the detriment of Canada's indigenous peoples, "as instruments of assimilation, [Canada's] treaties advanced policy that sought not just to extinguish title but also to extinguish the Aboriginal identity." ${ }^{28}$ Under the direction of the federal government, Inuit lands were ceded; relocation was commonplace, in many cases for the purpose of securing Canada's northern sovereignty. However, the practice of treaty-making did not completely abate. The 1973 Supreme Court of Canada Calder decision established that indigenous rights pre-existed the 1763 Proclamation and set the context for future land claims agreements. ${ }^{29}$ Accordingly, Tony Penikett explains that the Proclamation established two important principles: recognition of indigenous title to the land, and the legitimacy of North American indigenous government. ${ }^{30}$ Though the Proclamation did not apply specifically to the Inuit, it set an important precedent for Canada's modern treaties and land agreements. That said, decades of government self-interest ensued prior to the negotiation of modernday treaties.

The 1940s and 1950s represent perhaps the period that was most destructive to Inuit socio-economic conditions. Adversely affected by collapse of the fur trade in the 1930s, and increasingly less able to feed and clothe themselves because of the declining caribou stock, many Inuit were pressed into government relocation programs, which moved them to regions further north, presumably for the purpose of continuing self-sufficiency. Despite this, many Inuit continued to lack the resources necessary to maintain even a subsistence-level existence.

Yet this relocation effort also served other purposes, related to first World War II and then the Cold War. The Royal Commission on Aboriginal Peoples, in its report on the High Arctic Relocation, concluded, "the relocation took place at a time when the government was concerned about de facto Canadian sovereignty arising from the

27 Légaré, "Canada's Experiment with Aboriginal Self-Determination in Nunavut," 340.

28 Ibid.

29 Bonesteel, "Canada's Relationship with Inuit," 104.

30 Penikett, "Northern Governance." 
presence of the United States in the Arctic," 31 although Inuit social and economic well-being was also a factor. Additionally, the increased level of North American military activity directed Canada's attention to the region's potential for natural resource extraction. Hugh Keenleyside, a former Deputy Minister of Mines and Resources, noted that, in addition to defense, "recognition of [the Arctic's] importance came also from a new appreciation of the economic possibilities." 32 The Canadian government was increasingly aware of its Far North, and an increased Inuit presence was an asset to Canada's assertion of sovereignty over its Arctic archipelago.

The legacy of this government policy resulted in a process of assimilation and acculturation that left many Inuit dependent, sedentary, and disillusioned. Children, forcibly removed from their homes to attend residential schools, learned English and the "virtues" of Christianity, contributing to the loss of native culture and language. Physical, emotional, and sexual abuse in the residential schools has been widely reported by former students, many of whom are still alive. ${ }^{33}$ Numerous government reports have attested to the adverse affects of the policy that led to this socio-economic hardship. ${ }^{34}$ On 11 June 2008, Prime Minister Stephen Harper delivered the longawaited apology to the Aboriginal People of Canada for the actions and policies of the Canadian government that resulted in "institutions [that] gave rise to abuse and neglect." ${ }^{35}$ However, the residential schools that inflicted indelible harm on many indigenous children also produced some of the greatest thinkers in Inuit society today.

31 Makivik Corporation, "Journal of the Inuit Sled Dog Internation," The Fan Hitch 7:2, (March 2005); available at http://homepage.mac.com/puggiq/V7N2/V7N2Nunavik. html.

32 Bonesteel, "Canada's Relationship with Inuit," vi.

33 Government of Canada, Indian and Northern Affairs Canada, "Evaluation of Community-Based Healing Initiatives Supported Through the Aboriginal Healing Foundation," (Ottawa, 7 December 2009).

34 As an example, see Bonesteel, "Canada's Relationship with Inuit," and Indian and Northern Affairs Canada, "Evaluation of Community-Based Healing Initiatives Supported Through the Aboriginal Healing Foundation."

35 Isuma TV, Truth and Reconciliation, "CBC Report: Canadian Apology," available at http://www.isuma.tv/lo/en/truth-and-reconciliation. 
THE QuARTERLY JOURNAL

\section{Inuit Today}

Jack Anawak, an Inuit activist and survivor of the residential school system, has played a large role in federal and territorial politics. From 1988 to 1997 he served as the parliamentary representative of Nunatsiaq and was a member of the first Legislative Assembly of Nunavut. ${ }^{36}$ Today, he says, "We need a Department of Imagination in government," referring to Nunavut's need to look forward at a time when some residents are questioning whether or not they were better off under the non-aboriginal administration of the Northwest Territories. ${ }^{37}$

Indeed, the Inuit standard of living still lags far behind that enjoyed by people of non-Aboriginal descent in the rest of Canada. Statistics Canada (November 2004) reports that the median age of the Inuit population is 20.6, compared to the nonAboriginal median age of 38. The high school graduation rate is meager, and only 3 percent of Inuit had attained a university degree. The median income of Inuit aged 25 to 54 was CAD 18,118 compared to the median non-Aboriginal income of CAD 30,023 , and the rate of unemployment among the Inuit is considerably higher than that of non-Aboriginal people. ${ }^{38}$ By official standards, housing in Inuit towns is either overcrowded or in need of major repair. According to Inuit Statistics, the rate of suicide is eleven times higher among the Inuit than that of non-Aboriginal people. ${ }^{39}$

Despite these pessimistic figures, many Inuit doggedly pursue plans for a future that combines self-government with an understanding of their strategic value as Canadians of the Far North. Accordingly, the Government of Nunavut was structured to blend the principles of Canadian parliamentary democracy with the values of Aboriginal cooperation to respond to community needs. Based on consensus, the government's decision-making is made by non-partisan majority vote. ${ }^{40}$ Because Inuit live in rural areas as well as urban centers, community needs are better addressed along non-partisan lines, particularly where educational and development opportunities are unequal.

36 Nunavut is an Inuktitut word meaning "our land."

37 Lisa Gregoire, "Territory of Unrequited Dreams," Canadian Geographic 129:1 (January/February 2009).

38 Statistics Canada, A Profile of Canada's Inuit Population (Ottawa: Government of Canada, November 2004).

39 Inuit Tapiriit Kanatami, "Inuit Statistical Profile 2008."

40 Legislative Assembly of Nunavut, "FAQS: What are the differences between the Provincial and Nunavut governments?," available at http://www.assembly.nu.ca/faq. 
In 1999, the first Legislative Assembly of Nunavut set out a list of principles called the Bathurst Mandate. The document outlines four priorities by which the Inuit will attain "independence and prosperity":

- Inuuqatigiittiarniq, the healthy inter-connection of mind, body and spirit

- Pijarnirniqaqsat katujjiqatigiinnirlu, simplicity and unity

- Ilippallianginnarniq, continuing learning

- Namminiq makitajunnarniq, self-reliance.

While all the priorities are of equal importance, for the purpose of this article I will focus on self-reliance. As the assembly declared:

Our government believes that as individuals we are responsible for our own lives, and through our own efforts and activities we can provide for the needs of our families and communities. As communities, and as a government, we are con nected to and reliant on each other, to care for those in need, to establish common goals and to secure the resources required to achieve those goals. This is nammi niq makitajunnarniq-self-reliance. ${ }^{41}$

The government of Nunavut claimed that it expected to be economically selfreliant and free of any external debt by the year $2020 .{ }^{42}$ However, impediments arising from fiscal restraints may hinder the government from meeting its goals. For instance, Nunavut relies on the Canadian federal government for 90 percent of its annual budget. ${ }^{43}$ In part, the problem arises from an arrangement between Ottawa and Nunavut whereby the majority of Nunavut's land is "owned by the federal government and all resources royalties and taxation that come from resource extraction (minerals, oil, gas) ... flow to the Canadian government." While slow to start, devolution negotiations are expected to establish territorial control over these resources, thereby resulting in greater autonomy and economic self-reliance.

Nunavut is not alone in its frustration with Ottawa. Mary Simon, President of ITK, argues that for all Inuit "education and skills development are the essential building blocks of almost all forms of economic development." 44

41 Government of Nunavut, Legislative Assembly of Nunavut, $3^{\text {rd }}$ Session, $1^{\text {st }}$ Assembly (Hansard, Nunavut, 20 October 1999).

42 Légaré, "Canada's Experiment with Aboriginal Self-Determination in Nunavut," 358.

43 Ibid., 358-59.

44 Mary Simon, "Background Notes For ITK President Mary Simon, Meeting with First Ministers and NAOs" (Ottawa, 15 January 2009); available at http://www.itk.ca/media-centre/media-releases/background-notes-itk-president-mary-simon-meeting-firstminister-and-nao. 
With a high school graduation rate of 25 percent, the population is destined to fail: suicide is more prevalent, social confidence is damaged, the possibility of producing future Inuit leaders decreases, and employment positions are filled by transient workers who "come to the Arctic and then leave again because it's not their home." 45

In 2005, Thomas Berger, a former judge on the British Columbia Supreme Court best known for postponing the Mackenzie Valley Pipeline project until all Aboriginal land claim agreements were settled, concurred with Simon, adding that the low rate of graduation in Nunavut "reinforces the colonial message of inferiority." 46 An educational system commensurate with the rest of Canada's and culturally attuned with Inuit existence, while initially costly, would create a confident and capable workforce. Berger added that by increasing the number of Inuit in local government jobs, the federal government would save "tens of millions of dollars per year in costs such as those associated with recruitment, hiring, and training of non-Inuit (most imported at considerable further expense from the South) for the same position." ${ }^{47}$ As climate change renders the Arctic increasingly accessible, an educated Inuit population would benefit the indigenous workforce, business, and government alike.

Mary Simon and John Merritt, chief legal counsel and senior policy consultant for ITK, are proponents of extensive port development, along with advocating for improved educational opportunities for the Inuit. In Merritt's 2009 testimony before the Standing Committee on National Defence, he argued for multi-purpose investment in ports in the Far North. Investment, he argued, would provide a means by which Canada could pursue its sovereignty and defense strategy. Second, for the Inuitthe majority of whom live along the coastline-port development would decrease the cost of goods and encourage the expansion of Inuit-owned commercial fisheries. Moreover, fishing boats in Canada's northern coastal region would provide additional support for Canada's assertion of sovereignty in the archipelago. ${ }^{48}$

Beyond national interests, the recognition of Greenland's geopolitical significance as a semi-autonomous region of Denmark has led to growing interest in Inuitbased regional alliances. Granted semi-autonomous status by Copenhagen in 1979, Greenland's 2008 referendum gave this predominantly Inuit population further control over internal affairs and rights to potentially lucrative Arctic resources. Though there is disagreement as to whether or not this will result in full independence, ${ }^{49}$

45 Government of Canada, House of Commons Standing Committee on National Defence, "Canada's Arctic Sovereignty," June 2010

46 Byers, Who Owns the Arctic, 113.

47 Quoted in Byers, 113.

48 Government of Canada, $40^{\text {th }}$ Parliament, $2^{\text {nd }}$ Session, Standing Committee on National Defence (Ottawa: 1 October 2009).

49 Heather Conley and Jamie Kraut. "U.S. Strategic Interests in the Arctic," Center for Strategic \& International Studies (April 2010): 19-21. 
Franklyn Griffiths suggests "Ottawa needs to promote and finance broader and deeper relations between Nunavut and Greenland with Denmark's support." ${ }^{50}$ Clearly, however, a Canadian Arctic strategy that encourages inter-state connections between regionally connected Inuit would need to focus more attention on the domestic human dimension and provide the requisite resources.

\section{The United States-Canada Partnership}

As is customary for incoming U.S. presidents, President Barack Obama made Canada his first state visit shortly after his January 2009 inauguration. With the exception of former President George W. Bush, who visited Mexico first, this has been standard protocol since the presidency of John F. Kennedy. ${ }^{51}$ On 19 February 2009, at the closing of a joint Obama-Harper press conference, Obama said, "I want also, by the way, to thank some of the Canadians who came over the border to campaign for me during the election." Humor aside, the press conference emphasized the new and ongoing security initiatives in which partnership is an imperative. Furthermore, with reference to the close economic relations between the neighbors, Obama noted, "We're joined together by the world's largest trading partnership." ${ }^{2}$ President Obama's speech emphasized the extent of the Canada-U.S. bond, which was forged under the principle of continentalism for mutual economic and security benefit. Perhaps for this reason, Lloyd Axworthy, Canada's former Minister of Foreign Affairs, has said: "Canadians have been accused of living north and looking south." ${ }^{3}$ That is, in so far as Canada and the U.S. are entrenched in trade and security relations, Canada's focus on its Arctic suffers.

This notion is not new to Canadians. George Grant, the acclaimed Canadian philosopher, argued in his 1965 Lament for a Nation that, by 1963, with Canada's sights set on economic growth, the idea of continentalism had rooted itself in the nation's corporate culture. Some of Canada's elite embraced the concept so warmly that the idea of nationalism came to be seen as something "old-fashioned" 54 and in opposition to progress.

50 Franklyn Griffiths, “Towards a Canadian Arctic Strategy," Foreign Policy For Canada's Tomorrow 1 (May 2009): 21.

51 CBC News, "Obama's Visit to Canada Will Be 'Sooner rather than later': Cannon," CBC.com, (20 January 2009).

52 “Transcript: Obama-Harper Press Conference," Toronto Star (19 February 2009).

53 Government of Canada, House of Commons Standing Committee on Foreign Affairs and International Trade, "Canada and the Circumpolar World: Meeting the Challenges of Cooperation into the Twenty-First Century" (Ottawa: April 1997), 37.

54 George Grant, Lament for a Nation: The Defeat of Canadian Nationalism, 40 ${ }^{\text {th }}$ Anniversary Edition (Montreal and Kingston: McGill-Queen's University Press, 2000), 41. 
He attributed this shift away from nationalism toward continentalism to the dominant force of the business elite based in Canada's southern metropolitan areas, who demanded a means by which the Canadian corporation could thrive. In other words, with the extensive growth of American capitalism, the increased success of Canadian corporations relied on integration into the U.S. corporate structure: therefore, a political party that wanted to succeed must produce policies in line with continentalism. Moreover, in Grant's view, "A society dominated by corporations could not vote for an independent defence policy." 55

Grant further argued that it was not, however, the aspirations of politicians or businessmen that would determine the ultimate course of action. It was the essence of modernity itself that meant "progress." Canada lived next to a "society that is the heart of modernity," and Canadians believed in the ideals of modernity. ${ }^{56}$ In other words, the continental approach was unavoidable.

\section{The Canada-U.S Economic Partnership}

According to the U.S. State Department, the U.S.-Canada trading partnership is the closest and most extensive in the world. In 2008, the U.S. exported USD 264.2 billion to Canada in merchandise inclusive of energy products. Concurrently, the U.S. imported USD 347.9 billion worth of goods and resources, ${ }^{57}$ representing 53 percent of Canada's GDP. ${ }^{58}$ The depth of this economic relationship is a result of the 1994 North American Free Trade Agreement (NAFTA), which reduced trade barriers between the United States, Canada, and Mexico. It superseded the U.S.-Canada Free Trade Agreement of 1989.

55 Ibid.

56 Ibid., 53.

57 U.S. State Department, "Background Note: Canada," available at http://www.state. gov/r/pa/ei/bgn/2089.htm.

58 Government of Canada, “The Canada-U.S. Trade and Investment Partnership," available at http://www.canadainternational.gc.ca/san_francisco/commerce_can/trade_ partnership-partenariat_commerce.aspx?lang=eng\&menu_id=35\&menu=L. 
An extensive part of this bilateral trade is attributed to Canada's wealth of natural resources. In energy products alone, the Canadian terrain is rich in oil, gas, and uranium along with an abundant capacity in hydroelectric power. Jim Prentice, Canada's then Minister of Industry, stressed this point in a 2008 address to Energy Magazine in Houston, Texas:

After your own production, Canada is the United States' largest supplier of energyelectricity, oil, natural gas, and uranium. Annual exports are close to $\$ 100$ billion.

Concerning oil, Canada has been the largest supplier to the U.S. since 1999—not

Saudi Arabia, not Kuwait, nor any other OPEC producer. ${ }^{59}$

Tied together with NAFTA, the United States Energy Policy of 2005 ensures the undisturbed flow of energy to the American market to meet the goal of North American energy freedom by $2025 .{ }^{60}$ A U.S. federal commission is tasked with making recommendations for coordination "within the three contiguous North American nation area of Canada, Mexico, and the United States" under the title of "Set America Free Act of 2005," or the "SAFE Act." 61

One initiative of this 551-page energy policy document tasks the Secretaries of Energy and Defense with forming a partnership with the Province of Alberta for the express purpose of developing the oil sands there (Section 369, Par. (4)). Furthermore, §2398a states: “The Secretary of Defense shall develop a strategy to use fuel produced, in whole or in part, from coal, oil shale, and tar sands ... and refined or otherwise processed in the United States." In other words, procuring U.S. energy requirements is vital to U.S. national security and the continued growth of the U.S. economy.

\section{The Canada-U.S. Defense and Security Partnership}

The complexity of Canada's post-World War II security and trade relations cannot be underestimated. By the time Prime Minister John G. Diefenbaker took office in 1957, the final decline of the British Empire was matched by the rising power of the United States. Canada was still strongly attached to Britain-indeed, the Canadian

59 The Honorable Jim Prentice, Minister of Industry, Energy Magazine "Country of the Year" Breakfast, Industry Canada (5 May 2008); available at http://www.ic.gc.ca/eic/ site/ic1.nsf/eng/01970.html.

60 The United States Energy Policy of 2005 has not been updated since, with the exception of a few minor amendments.

61 United States Congress, "Energy Policy Act of 2005," PL 109-58, 109 ${ }^{\text {th }}$ Congress (8 August 2005), 472. 
Constitution was not patriated until 1982, representing the nation's final separation from Britain. Diefenbaker considered Britain "an essential counterweight to U.S. influence." ${ }^{2}$ However, the 1950 s were also the period that cemented the CanadaU.S. security and defense relationship that began in 1938. In the throes of Cold War geopolitics, the NATO alliance was increasingly important; in 1957, the North American Air Defense Command (NORAD) integrated both nations' air defense systems under joint command based in Colorado. ${ }^{63}$ Post-World War II geopolitics demanded unequivocally bilateral defense of the North American continent, and simply extended a strategy that had been initiated earlier. ${ }^{64}$

In 1938, U.S. President Franklin D. Roosevelt and Canadian Prime Minister Mackenzie King entered into a "security bargain," which became the basis for the postwar approach to continental defense. The U.S. pledged that it "would not stand idly by" should Canada be attacked, while Canada agreed to prevent attack "either by land, air, or sea, to the United States across Canadian territory." 65 Explicit to the agreement was that both countries would offer assistance in times of threat. But differences arose: the U.S., for its part, promised to actively defend Canada, whereas Canada did not reciprocate. Rather, it undertook to defend its national territory in order to prevent an attack on the U.S., without offering assistance to repel an invasion of the continental U.S.

Thereafter, Canada pursued a policy position of "defense against help." Defense analysts Donald Barry and Duane Bratt explain the strategy thus: this strategy pursued by "mid- or small-sized states maintains a sufficient level of defense unilaterally, or in cooperation with a large state that is committed to its safety, to avoid 'unwanted help' from the larger state." ${ }^{\text {"66 }}$ However, this did not preclude North American defense as its primary goal.

In 1940, the two countries agreed to engage in policy-level consultations on bilateral defense matters by creating the Permanent Joint Board on Defense. ${ }^{67}$ Since then, the bilateral defense relationship between the U.S. and Canada has resulted in more than 2,500 agreements. ${ }^{68}$

62 H. Basil Robinson, Diefenbaker's World: a Populist in Foreign Affairs (Toronto: University of Toronto Press, 1989), 4.

63 Robinson, Diefenbaker's World, 3-9. Also see Grant, xiv.

64 Grant, Lament for a Nation, 49.

65 Donald Barry and Duane Bratt, "Defense Against Help: Explaining Canada-U.S. Security Relations." American Review of Canadian Studies 38:1 (March 2008): 64.

66 Nils Orvik, as quoted in ibid., 63.

67 U.S. State Department, "Background Note: Canada.

68 Government of Canada, National Defence and the Canadian Forces, "Defence Cooperation: Principal Agreements," available at http://www.forces.gc.ca/site/focus/ canada-us-canada-eu/agree-accords-eng.asp. 
The Cold War era reinforced the U.S.-Canada defense bond, as the Soviet threat took shape. A 1945 Canadian government report noted that, "although the possibility of foreign attack was remote, North American vulnerability would grow with advances in weapons technology." 69 As a result, containment expanded north to the Arctic and across the Atlantic to Europe. In 1949, the U.S. and Canada were among the founding members of the North Atlantic Treaty Organization (NATO). By 1954, bilateral agreements resulted in the Distant Early Warning (DEW) Line along the seventieth parallel, and the formation of the North American Aerospace Defense Command (NORAD) to monitor continental airspace and air sovereignty. ${ }^{70}$

Canada, then and later, "would not articulate the defense against help strategy often," but the principal strategy remained in place. ${ }^{71}$ When Canada does articulate the principle of "defense against help," it often leads to acrimony between Ottawa and Washington, as was the case with Diefenbaker's 1961 decision to deny President John Kennedy's request to place nuclear warheads on Canadian soil. ${ }^{72}$ In part, this contentious bilateral issue led to the failure of Diefenbaker's reelection attempt in 1963.

In 1968, the newly elected Trudeau government commissioned a reassessment of Canada's foreign and defense policy that found Cold War tensions to be waning. As a result, Canada refocused its defense strategy away from NATO and strengthened its role in NORAD. The U.S. welcomed Canada's increased interest in continental defense, but James Schlesinger, then U.S. Secretary of Defense, argued, "we will soon have nothing more than the North American continent to defend." European decision makers concurred, and linked Canada's NATO contribution to the expansion of European trade relations. ${ }^{73}$ By the time Trudeau retired in 1984, "the NATO and NORAD commitments had recouped much of their original importance." 74

While Trudeau (Prime Minister from 1968-79 and 1980-84) was not considered the "darling" of the military (and was even derided as a "pinko" by some), defense spending under his administration was relatively high. A 2007 analysis of Canadian defense spending found that, in the last thirty-seven years, military spending dropped from its high of 2 percent of GDP in 1970, followed by a long period of cuts. By 1983, most cuts had been recouped, and spending returned to 1.9 percent of GDP. In subsequent years, spending hovered around a low of 1 percent. The same report notes that the current Harper government, regarded as a proponent of the military, allocates

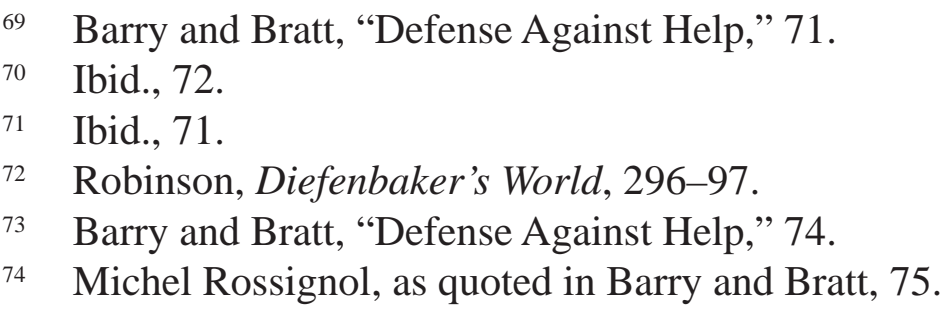




\section{2 percent of GDP to military spending. ${ }^{75}$}

Given that Canada's defense spending is relatively low in comparison to that of the United States (3.5 percent of $\mathrm{GDP}^{76}$ ), Washington has been known to place pressure on Ottawa to increase spending. In 2004, the U.S. Ambassador to Canada, Paul Cellucci, was tasked with convincing Ottawa to increase its level of military spending. In light of the events of 11 September 2001, Canada had already increased its spending on defense, and in 2005 it announced an additional increase. Simultaneously, the Paul Martin government was quietly considering participation in the U.S. ballistic missile defense program. However, to the chagrin of Martin, when President Bush publically revealed the possible missile defense plan, an already weak Martin government was forced to backpedal. This came at the height of the Iraq War, and the majority of Canadians had neither tolerance for the war itself nor for any action that smacked of U.S. unilateralism. Moreover, the Martin government was further challenged in February 2005 when Canada's incoming ambassador to the United States, Frank McKenna, publicly stated: "Canada was effectively already participating in missile defense as a result of changes made to NORAD the previous summer." Yet the following day, then-Foreign Minister Pierre Pettigrew countered, "Canada would not participate in the U.S. [ballistics missile] program." "77 Andrew Richter, an assistant professor at Windsor University, argued that this answer of "no" sent the message that Ottawa "was no longer interested in cooperating with Washington on North American security." 78 But alongside support for bilateral defense, Canada's priorities often focus elsewhere. As Richter points out, "Canadians have a limited tolerance for defence spending, and at some point they will not accept further investments in the country's military ahead of programs like health and education." 79

That said, in light of the security risks stemming from the 11 September 2001 terrorist attacks, "cooperation has broadened beyond conventional defense to include non-military aspects of security." ${ }^{00}$ Joel Sokolsky, Principal of Canada's Royal Military Academy, predicts that such collaboration "will become more important than traditional military cooperation." 81

75 David Pugliese, “Trudeau was Canada's Top Defense Spender: Study,” National Post [Toronto] (2 December 2007).

76 Andrew Richter, "Permanent Allies? The Canada-U.S. Defense Relationship in the $21^{\text {st }}$ Century," Journal of Military and Strategic Studies 12:1 (Fall 2009): 19.

77 Ibid., 13-15.

78 Ibid., 17.

79 Ibid., 25.

80 Barry and Bratt, "Defense Against Help," 81.

81 As quoted in ibid., 81. 
For example, at present Bill C-42 seeks to amend Canada's Aeronautics Act. If passed, airlines would be required to submit passenger lists to U.S. authorities for all flights departing Canada and flying over U.S. airspace, in compliance with the U.S. Department of Homeland Security's Secure Flight Program. ${ }^{82}$ The Liberal opposition is arguing that this requirement threatens Canadian sovereignty. ${ }^{83}$ However, given that Canada does not want to be seen as the weak link in continental defense, going forward Canada's security measures will be increasingly linked to U.S. security interests.

In sum, then, the U.S.-Canada defense and trade relationship is substantial, to the extent that defense appears linked to trade and vice versa. For example, in 1983 Prime Minister Trudeau consented to a U.S. request to test ballistic missiles on Canadian soil, in opposition to public opinion. This resulted in the U.S. government issuing Canada an exemption from tariffs on foreign steel. ${ }^{84}$ In contrast, the Martin government refused to participate in the U.S.-led ballistic missile program. By coincidence (or perhaps not), U.S. "protectionism on matters ranging from softwood lumber to beef imports" was extensive during this time. ${ }^{85}$ But beyond these concrete examples of the interconnection between bilateral trade and defense, it is important to remember that the underlying premise of Canada's defense strategy is "defense against help." For Canada, sovereignty remains a thorny issue, particularly if ever she should perceive any threat to her sovereign authority from her partner to the south. From the U.S. perspective, Canada is expected to uphold her side of the security bargain in the interests of continental defense. However, Canada's interpretation of the United States' expectations is not always clear-cut, which may hold true in defense and security matters concerning the Arctic.

\section{U.S. Policy in the Arctic Region and Beyond}

The United States' interests in the Arctic were clearly articulated on 9 January 2009 when outgoing President George W. Bush released the ten-page "National Security and Homeland Security Presidential Directive," or the "Arctic Region Policy." Scott Borgerson, from the Council on Foreign Relations, touted it as a "vast improvement" to the antiquated 1994 policy. Nevertheless, he also argued that the policy “

82 United States Government, Transportation and Security Administration, Secure Flight Program, available at http://www.tsa.gov/what_we_do/layers/secureflight/.

83 Kevin Dougherty, "Uncle Sam Wants Your Data," The Gazette [Montreal] (29 June 2010).

84 Barry and Bratt, "Defense Against Help," 75.

85 Ibid., 79. 
unnecessarily pokes Canada in the eye over Arctic sovereignty." 86

In particular, the policy states: "Freedom of the seas is a top national priority. The Northwest Passage is a strait used for international navigation, and the Northern Sea Route includes straits used for international navigation; the regime of transit passage applies to passage through those straits." This was a critical departure from the strategy of "agree to disagree" that had previously been pursued by both Canada and the U.S.

Canada considers the Northwest Passage to be "internal waters," which implies that she retains sovereign control over maritime traffic through the Passage. Conversely, the U.S. defines the waters as an "international strait," which guarantees freedom of navigation for international vessels. It is argued that by asserting this right of control, Canada could set a precedent whereby other countries, such as Iran, could assert control over passages like the Strait of Hormuz, waters now legally considered international. That said, Cellucci and Borgerson have both suggested that if Canada were to increase its Arctic defense capabilities, the U.S. "might look the other way" should Canada assert its claim to the Passage. ${ }^{87}$

Initially the U.S. Arctic Policy drew little attention in Canada. Harper's reaction was temperate, stating only that "we have some disagreements" over the sovereignty of Arctic maritime borders. But Canada's objective is to work "cooperatively" so "that it does not become a route for smuggling or other kinds of security risks." 88 However, this seemingly complaisant attitude shifted on 20 August 2010, when Foreign Minister Lawrence Cannon released the "Statement on Canada's Arctic Foreign Policy: Exercising Sovereignty and Promoting Canada's Northern Strategy Abroad." The message was clear: "In our Arctic foreign policy, the first and most important pillar towards recognizing the potential of Canada's Arctic is the exercise of our sovereignty over the Far North." ${ }^{89}$ Shortly after, Harper stated that Canada's sovereignty is "non-negotiable."

86 Scott Borgerson, "New U.S. Arctic Policy Gets It Mostly Right," Securitydebrief.com (13 January 2009).

87 Rob Huebert, "United States Arctic Policy: The Reluctant Arctic Power," University of Calgary School of Public Policy Briefing Papers 2:2 (May 2009).

88 Jeff Davis, "Canadian Response to New U.S. Arctic Policy Muted," Embassy (21 January 2009).

89 Government of Canada, "Statement on Canada's Arctic Foreign Policy: Exercising Sovereignty and Promoting Canada's Northern Strategy Abroad," (Ottawa: 24 August 2010). 
Canada's Arctic analysts had a mixed reaction. Michael Byers welcomed the switch from military to diplomatic rhetoric, but was not convinced the message was effectively conveyed. Rob Huebert criticized the government for "dual messaging," but noted (along with Ken Coates) that the sovereignty issue raises the sense of Canadian nationalism. ${ }^{90}$ Franklyn Griffiths has argued that Canadian politicians typically turn to Arctic sovereignty as a conduit for "identity politics' so as to bolster appearances of attachment to the True North and to put distance between themselves and the United States." 91

While the intent of the statement remains to be seen, a policy of joint cooperation has ultimately prevailed in matters of importance to North American security. As in the past, squabbles between the U.S. and Canada will most likely be artfully resolved behind the closed doors of diplomatic chambers. With 2500 joint defense agreements between them, and the mutually agreed upon principles of continental defense and security, neither side is prepared to let this bilateral security bargain fall into disrepair.

Thus far, Canadian and U.S. Arctic analysts alike have tended to focus on the "hard" security measures associated with defense. However, the exceptional number of "soft" security measures addressed in both the official U.S. and Canadian statements of Arctic policy have been largely overlooked: cooperation, governance, sustainable development, environmental protection and climate change, science, and the engagement and support of Arctic indigenous peoples. Canada's failure to recognize the full importance of these "soft" security issues is arguably misguided.

That each nation has its own strengths that it brings to bear in regard to Arctic defense and security needs to be taken into account. I would argue that the effectiveness of Canada's defense and security strategy resides to a great extent in the presence of Canada's Inuit who, if regarded as more than "unassuming" defenders of Canada's sovereignty, could play an integral part as contributors to the rising interest in nonmilitary security measures. As was demonstrated by a recent statement by U.S. Secretary of State Hillary Clinton, disregard of indigenous participation is no longer acceptable.

In March 2010, Clinton publicly rebuked Canada for holding an Arctic summit in Chelsea, Quebec to which the five Arctic coastal states (Canada, Denmark, Norway, the Russian Federation, and the United States) alone were invited.

90 Anca Gurzu, "New Arctic Policy Involves 'Good Cop—Bad Cop' Strategy," Embassy (25 August 2010); available at http://www.embassymag.ca/page/view/arctic-08-25-2010.

91 Griffiths, "Towards a Canadian Arctic Strategy," 26. 
The Inuit, in addition to the other three Arctic nations (Finland, Iceland, and Sweden) that comprise the Arctic Council, were not invited. Clinton stated: "Significant international discussions on Arctic issues should include those who have legitimate interests in the region." ${ }^{92}$ While Canadian Foreign Affairs Minister Lawrence Cannon said he thought all participants made a clear distinction between the role of the Arctic Council and that of the Arctic rim states, ${ }^{93}$ observers noted that this marked an end to Arctic summits without full participation of all Arctic Council members. This was not the first time that Finland, Iceland, and Sweden and indigenous peoples had been left out; in May 2008, the Arctic rim states met in Greenland to write the Ilulissat Declaration.

Clinton was clear: the participation of all Arctic Council members should now be considered the status quo. As this relates to Canada, this suggests that Inuit inclusion is essential to international discussions. Perhaps Clinton was signaling Canada to look outside of its traditional defense strategy to bolster its Arctic capacity through cultivating the Inuit presence in pursuit of continental security and defense. But to do so, Canada needs first to implement its land claims agreements: "Settling of land claims is only part of the story, for Canada does not do particularly well implementing them once signed." 94

The Canada-U.S. security and trade relationship is complex, but the true depth of the relationship is often overlooked because the two nations are the epitome of good neighbors. That said, the security and defense relationship takes considerable work. Maintaining the relationship is rather like a high wire performance, with each step carefully calculated to attain the highest degree of success. Success is the only solution. And in terms of trade, the relationship could be likened to the traditional American Thanksgiving celebration: a bounty of riches to be shared by both parties.

\section{Conclusion}

Given the complex state-centric issues arising from the bond between the United States and Canada on economic and security issues, the "soft power" issues regarding Inuit development and self-determination tend to command a lesser position on the national agenda. That said, a policy position that conceptualizes Canada's Arctic as a robust region associated with resource exploitation and defense capabilities alone may neglect the essential role that Inuit socio-economic development could contribute toward Canada's claim to "Arcticness."

92 Bob Weber, "Criticism of Arctic Guest List Welcomed by Inuit," Globe and Mail [Toronto] (31 March 2010).

93 Ibid.

94 Coates, Arctic Front, 204. 
That Canada and the United States are entrenched in a truly continental relationship cannot be overlooked. However, Canada's approach to its Arctic strategy needs to consider the manner in which its security and defense relations are interpreted beyond "hard" security and defense measures, particularly as articulated in the United States' Arctic strategy. If, as Sokolsky argues, the role of non-military security cooperation has increased in significance within the bilateral relationship, a Canadian Arctic strategy focused on Inuit development and regional infrastructure could provide essential tools for a more robust Canadian Arctic presence as well as satisfy U.S. interests.

Lastly, one might say that the Inuit are on a quiet crusade to fulfill their desire for self-determination. Inuit strategy seeks to satisfy not only community needs, but also to solidify their status as Canadian citizens, and to align their interests with the Canadian government. Internationally recognized conventions related to indigenous rights and Canada's land claim agreements are too far gone to recede into the woodwork. The Inuit are patient, but they are also stalwart in their pursuit of self-determination, as is evidenced in the filing of grievances against the Canadian government. Inuit elites are politically savvy and operate within the recognized political system to accomplish their strategic goals. What Canadian policy makers need to ask is whether or not the traditional view of security and defense actually delivers the desired results. 
THE QUARTERLY JOURNAL

\section{Bibliography}

Simon, Mary. "Sovereignty for the North." The Walrus (2007).

Watt-Cloutier, Sheila. Bringing Inuit and Arctic Perspectives to the Global Stage: Lessons and Opportunities In 14th Inuit Studies Conference: Inuit and Arctic Perspectives . Calgary: University of Calgary, 2005.

Légaré, André. "Canada's Experiment with Aboriginal Self-Determination in Nunavut: From Vision to Illusion." International Journal on Minority and Group Rights 15, no. 2 (2008): 336.

Penikett, Tony. A Report and Recommendations for Canadian Foreign Policy in the Circumpolar Arctic, Appendix 3, "Northern Governance: Devolution, Treaties and the Arctic Council”. Ottawa: Canadian Arctic Resources Committee, 1997.

Byers, Michael. Who Owns the Arctic: Understanding Sovereignty Disputes in the North. Vancouver: Douglas \& McIntyre, 2009. 